\title{
ANALISIS USAHATANI TOMAT (Lycopersicon esculentum Mill) DI DESA MANDESAN KECAMATAN SELOPURO KABUPATEN BLITAR
}

\author{
Yusuf Efendi \\ Program Studi Agribisnis Fakultas Pertanian Universitas Islam Balitar Blitar
}

\begin{abstract}
Abstrak
This research was conducted in Farmers Group Karya Maju located in the village Mandesan Selopuro Blitar districts, the data retrieved from the main data of the farmer members of the group as respondents, the research method used is observation, interview and Analisia. The results showed that 1) Analysis of farming tomatoes in Farmers Karya Maju allocate available resources effectively and efficiently to earn income at a certain time of Rp. 44,804,822, - 2) A financial analysis of farming tomatoes in Karya Maju Farmers Group to determine whether farming is done feasible and profitable to be developed or is said to be still in efensiensi level. $R$ / $C$ ratio of 1.8 indicates that the worth of the cost of $R p .54,095,828$, - will be obtained receipts by 1.8 times as much. In other words, the sale of tomatoes reached $1.8 \%$ of the capital that has been allocated. $R$ / $C$ Ratio worth more than 1 , indicating that the tomato farming qualified / eligible to be developed.
\end{abstract}

Keywords : tomato farming, tomato, farming.

\section{PENDAHULUAN}

Dari pengamatan yang dilakukan peneliti masyarakat Kelompok Tani Karya Maju banyak mengalami keamakmuran, sehingga bisa dikatakan sukses dalam usahataani tomat. Yang mana Desa Mandesan Kecamatan Selopuro Kabupaten Blitar sangat strategis yaitu terletak pada ketinggian 0-1.250 mdpl. Dengan keadaan suhu pada waktu siang $24^{\mathrm{oC}}$, sedangkan malam hari $15^{\mathrm{oC}}-20^{\mathrm{oC}}$. Kelembapan rata - rata $50-60 \%$, dengan banyaknya intensitas penyinaran 5 - 8 jam/hari. Curah hujan rata - rata 750 $\mathrm{mm} /$ tahun.

Jenis tanah di Desa Mandesan ini sangat cocok untuk ditanami tanaman tomat. Dimana tanah di Selopuro ini stuktur atasnya remah, teksturnya gembur, daya ikat tanah terhadap air tinggi, bahan organik di dalam tanah tidak cepat tercuci oleh air, dan $\mathrm{pH}$ tanah 5,82.

Berdasarkan uraian di atas dapat dilihat peluang pengembangan usaha tomat semakin luas. Sehingga dirasa penting untuk mempelajari dan melakukan penelitian dalam budidaya tomat dan penelitian ini mengambil judul "Analisis Usahatani Tomat (Lycopersicon Esculentum Mill) Pada Kelompok Tani Karya Maju di Desa Mandesan Kecamatan Selopuro Kabupaten Blitar". Adapun rumusan masalah yang dapat kami susun adalah sebagai berikut Bagaimana analisis usahatani tomat di 
Kelompok Tani Karya Maju Desa Mandesan? Dan bagaimana analisis finansial tomat di Kelompok Tani Karya Maju Desa Mandesan? Sedangkan tujuan penelitian ini yaitu untuk mengetahui analisis usahatani tomat di Kelompok Tani Karya Maju Desa Mandesan serta untuk mengetahui analisis finansial tomat di Kelompok Tani Karya Maju Desa Mandesan.

Menurut Soerkartawi (1995) bahwa ilmu usaha tani ilmu yang mempelajari bagaimana seorang mengolasikan sumber daya yang ada secara efektif dan efensien untuk memperoleh keuntungan yang tinggi pada waktu tertentu. Dikatakan efektif bila petani atau produsen dapat mengalokasikan sumberdaya yang mereka miliki (yang dikuasai) sebaik-baiknya; dan dikatakan efisien bila pemanfaatan sumberdaya tersebut menghasilkan keluaran (output) yang melebihi masukan (input).

Pada umumnya ciri usahatani di Indonesia adalah berlahan sempit, modal relatif kecil, pengetahuan petani terbatas, kurang dinamis sehingga berakibat pada rendahnya pendapatan usahatani (Soekartawi et al, 1986). Menurut Rahim dan Hastuti (2008).

Menurut Suratiyah (2009), faktor-faktor yang mempengaruhi besarnya biaya dan pendapatan sangatlah kompleks. Namun demikian, faktor tersebut dapat dibagi dalam dua golongan. Pertama adalah faktor internal dan eksternal, dan kedua adalah faktor manajemen. Faktor internal dan eksternal akan bersama-sama mempengaruhi biaya dan pendapatan usahatani. Faktor internal yang akan mempengaruhi biaya dan pendapatan usahatani yaitu: (1) umur petani, (2) pendidikan, pengetahuan, pengalaman dan keterampilan, (3) jumlah tenaga kerja keluarga, (4) luas lahan, dan (5) modal. Sedangkan faktor eksternal yang mempengaruhi dari segi input adalah ketersediaan dan harga input, sedangkan dari segi output adalah permintaan dan harga jual.

Menurut Soekartawi (2002), penerimaan usahatani adalah perkalian antara produksi dengan harga jual, biaya usahatani adalah semua pengeluaran yang dipergunakan dalam suatu usahatani dan pendapatan usahatani adalah selisih antara penerimaan dan pengeluaran. Menurut Soekartawi et al. (1986), terdapat beberapa istilah yang digunakan dalam melihat pendapatan usahatani yaitu pendapatan kotor usahatani dan pendapatan bersih usahatani. Pendapatan kotor usahatani (gross farm income) didefinisikan sebagai nilai produk total usahatani dalam jangka waktu tertentu, baik yang dijual maupun yang tidak dijual. Dalam menaksir pendapatan kotor, semua komponen yang tidak dijual harus dinilai berdasarkan harga pasar. Pendapatan bersih usahatani (net farm income) adalah selisih antara pendapatan kotor dengan pengeluaran total usahatani. Pendapatan bersih usahatani mengukur imbalan yang diperoleh keluarga petani dari penggunaan faktor-faktor produksi tenaga kerja, pengelolaan dan modal milik sendiri atau modal pinjaman yang diinvestasikan kedalam usahatani.

Pengeluaran total usahatani (total farm expenses) adalah nilai semua input yang habis terpakai atau dikeluarkan di dalam produksi, tetapi tidak termasuk tenaga kerja keluarga petani. Pengeluaran usahatani mencakup pengeluaran tunai dan tidak tunai. Pengeluaran tunai adalah pengeluaran berdasarkan nilai uang sehingga segala pengeluaran untuk keperluan usahatani yang dibayar dalam dalam bentuk benda tidak temasuk dalam pengeluaran tunai.

Tanaman tomat (Solanum lycopersicum L.), ditanam di indonesia sesudah kedatangan orang belanda, tanaman tomat termasuk tanaman semusim yang berumur 
pendek, artinya umur tanaman hanya satu kali produksi dan setelah itu mati. Tanaman tomat sangat bermanfaat bagi tubuh manusia, karena mengandung vitamin dan mineral yang diperlukan untuk pertumbuhan dan kesehatan. Dalam tomat juga terdapat zat pembangun jaringan tubuh dan zat yang dapat meningkatkan energi. Hal ini menandakan bahwa tanaman tomat sudah tersebar di seluruh dunia, baik di daerah tropik maupun subtropik (Cahyono, 1998).

Seperti tanaman yang lainnya, tanaman tomat mempunyai bagian - bagian tanaman seperti akar, batang, daun, bunga, buah dan biji.

\section{METODE PENELITIAN}

Penilitian ini dilaksanakan di Kelompok Tani Karya Maju, yang berada di sebelah timur kabubaten Blitar Kec. Selopuro Desa Mandesan. Adapun waktu penelitian ini kurang lebih satu bulan, yaitu dari tanggal 13 Maret - 13 April 2014.

Metode pengambilan sampel yang digunakan adalah metode Sensus. Metode ini digunakan karena jumlah petani Kelompok Tani Karya Maju yang mengusahakan tanaman tomat di Desa Mandesan adalah 20 petani. Menurut Kartono (1990), apabila populasi yang jumlahnya 10 - 100 orang sebaiknya diambil sampel 100\% atau perhitungan secara sensus.

Metode Pengumpulan Data yaitu dengan Observasi, wawancara, dan studi pustaka. Observasi atau pengamatan yang dilakukan untuk mendapatkan data dalam menganalisis usahatani tomat dan finansial. Observasi ini dilakukan pada Kelompok Tani Karya Maju dengan melihat secara langsung dalam usaha tani tomat. Sedangkan wawancara yang dilakukan meliputi: a) Melakukan tanya jawab dengan petani Kelompok Tani Karya Maju atau pihak yang terkait menyangkut hal - hal yang berhubungan dengan kegiatan budidaya tanaman tomat; dan b) Identifikasi masalah dan mencari pemecahannya kemudian didiskusikan dengan petani Kelompok Tani Karya Maju atau pihak yang terkait kemudian dibandingkan dengan kondisi yang ada di lapangan. Pengumpulan data dengan cara memanfaatkan data yang tersedia yang berhubungan dengan penelitian. Data tersebut bersumber dari buku, internet, arsip, dan lain sebagainya yang bersifat informatif dan relevan.

Metode Analisa data yaitu perhitungan Biaya, perhitungan penerimaan, dan perhitunga pendapatan. Perhitugan biaya yaitu perhitungan yang dilakukan secara perusahaan yaitu meliputi : biaya tenaga kerja, besarnya biaya produksi. Perhitungan penerimaan yaitu besarnya pendapatan kotor atau penerimaan. Sedangkan perhitungan pendapatan yaitu pendapatan atau keuntungan usaha tani merupakan selisih antara total penerimaan dengan total biaya.

Analisa kelayakan usaha yaitu Analisis efisiensi yang bertujuan untuk mengetahui apakah hasil usahatani budidaya tomat tersebut efisien atau tidak, maka antara analisa R/C Ratio ( Return Cost Ratio ), dimana R/C Ratio merupakan perbandingan antara penerimaan dengan produksi.

Break Event Point (BEP) adalah titik pulang pokok, dimana Total Reveneu sama dengan total cost, (Sunarjono, 2000). 


\section{Analisis Usaha Tani Tomat}

\section{HASIL \& PEMBAHASAN}

Adapun analisis usaha tani dalam budidaya tanaman tomat di Kelompok Tani Karya Maju per hektar (ha) dalam satu musim tanam mencakup 4 hal adalah sebagai berikut : Biaya tetap, Biaya variabel, biaya total, analisis pendapatan, analisis kelayakan usaha tani (R/C Ratio) dan BEP usaha tani.

\section{Biaya tetap}

Biaya tetap adalah biaya yang relatif tetap jumlahnya dan terus dikeluarkan walaupun produksi yang diperoleh banyak atau sedikit, jadi, besarnya biaya tetap tidak tergantung pada besar kecilnya produksi. Biaya tetap dalam penelitian ini adalah biaya pajak lahan, biaya sewa lahan, dan biaya penyusutan alat pertanian. Biaya tetap di hitung dari lahan yang akan di garap sebesar 1 ha dalam semusim tanam tomat.

Biaya tetap yang dikeluarkan oleh Kelompok Tani Karya Maju meliputi biaya sewa traktor, biaya sewa lahan, dan biaya tali ikat. Jumlah biaya sewa traktor yang hanya digunakan rata-rata responden adalah Rp 664.000,-. Jumlah biaya tali ikat yang digunakan responden rata- rata responden $\mathrm{Rp}$ 195.500,-. Jumlah biaya sewa lahan rata-rata yang digunakan 20 responden adalah Rp 15.640.000,-. Adapun penyusutan alat pertanian diambil Rp. 368.500,-. Dan biaya untuk pengadaan tangki dan gembor rata-rata responden Rp. 1.000.000,-. Jadi total biaya tetap rata-rata responden adalah Rp. 18.368.700,-.

Adapun biaya tetap terangkum dalam tabel di bawah ini :

Tabel 4.4. Analisis Usaha Tani Tanaman Tomat (Solanum lycopersicum L.) Di Kelompok Tani Karya Maju skala perhektar.

\begin{tabular}{llrl}
\hline No. Uraian & Volume & Status (Rp) & Jumlah (Rp) \\
\hline 1 & Sewa tanah 1 musim tanam & 15.640 .000 & \\
2 & Sewa Traktor & 664.700 & \\
3 & Tali Ikat & 195.500 & \\
4 & Tangki dan Gembor & 1.000 .000 & \\
$\mathbf{5}$ & Penyusutan alat & 368.500 & Total \\
\hline
\end{tabular}

Sumber : Hasil pengolahan data penelitian, 2015

\section{Biaya sarana produksi (Biaya Variabel)}

Biaya sarana produksi terdiri dari biaya benih, pupuk, pestisida dan tenaga kerja. Rincian penggunaan benih, pupuk pestisida dan tenaga kerja per hektar per musim tanam pada usahatani tomat di Desa Mandesan untuk petani anggota Kelompok Tani Karya Maju dapat dilihat pada tabel di bawah ini. 
Tabel 4.5.Analisis Usaha Tani Tanaman Tomat (Solanum lycopersicum L.) Di Kelompok Tani Karya Maju skala perhektar.

\begin{tabular}{|c|c|c|c|c|}
\hline No. & Uraian & Volume & Status (Rp) & Jumlah (Rp) \\
\hline 1. & benih & $2.346 \mathrm{gr}$ & 6.600 & 1.548 .360 \\
\hline \multirow[t]{3}{*}{2.} & mulsa & & & \\
\hline & a. mulsa plastik & 23 rol & 700.000 & 16.422 .000 \\
\hline & $\begin{array}{l}\text { b. polibag plastik } \\
\text { pupuk }\end{array}$ & 51 bungkus & 17.000 & 864.110 \\
\hline \multirow{3}{*}{3.} & a. ponska & $430 \mathrm{~kg}$ & 8.000 & 3.440 .800 \\
\hline & b. TSP/SP36 & $68 \mathrm{~kg}$ & 2.500 & 171.063 \\
\hline & c. pupuk kandang & 5.865 & 170 & 997.050 \\
\hline \multirow[t]{5}{*}{ No. } & Uraian & Volume & Status (Rp) & Jumlah (Rp) \\
\hline & d. mas hitam/ NPK hitam & $156 \mathrm{~kg}$ & 9.000 & 1.407 .600 \\
\hline & e. KNO3 & $82 \mathrm{~kg}$ & 11.000 & 903.210 \\
\hline & f. atonik & $782 \mathrm{ml}$ & 10.000 & 39.100 \\
\hline & g. metalik & $391 \mathrm{ml}$ & 125 & 48.875 \\
\hline \multirow[t]{5}{*}{4.} & pestisida & & & \\
\hline & a. dithane M-45 & $8 \mathrm{~kg}$ & 60.000 & 469.200 \\
\hline & b. curacron & 8 liter & 43.000 & 336.260 \\
\hline & c. roundup & $1.564 \mathrm{ml}$ & 100 & 1.564 \\
\hline & d. pelekat (APSA) & $3.910 \mathrm{ml}$ & 20 & 78.200 \\
\hline \multirow[t]{8}{*}{5.} & tenaga kerja & & & \\
\hline & a. persemaian (1Hok) & 20 org wanita & 35.000 & 684.250 \\
\hline & $\begin{array}{l}\text { b. pengelolaan lahan s/d } \\
\text { Siap tanam (7Hok) }\end{array}$ & 20 org pria & 45.000 & 6.158 .250 \\
\hline & c. tandur/tanam (1hok) & 20 org wanita & 35.000 & 684.250 \\
\hline & d. penyiangan,(2Hok) & 8 org pria & 45.000 & 351.900 \\
\hline & $\begin{array}{l}\text { e. Penyemprotan, } \\
\text { Pestisda s/d panen }\end{array}$ & 4 org pria & 45.000 & 175.950 \\
\hline & f. pemupukan (kocor) & 12 org wanita & 35.000 & 410.550 \\
\hline & g. panen \& pengangkutan & 20 org pria & 45.000 & 879.750 \\
\hline \multicolumn{2}{|c|}{ Total Biaya variable } & & & 36.227.128 \\
\hline
\end{tabular}

Sumber : Hasil pengolahan data penelitian, 2015

\section{Benih}

Benih yang digunakan oleh petani responden Kelompok Tani Karya Maju adalah jenis Benih Lentana. Jumlah benih yang digunakan oleh 20 responden adalah sebanyak 12.000 gram dengan rata-rata jumlah benih per responden adalah sebanyak 600 gram dengan rata-rata harga gram yaitu Rp 6.600,- . Jadi jumlah biaya benih yang digunakan 20 responden adalah $\mathrm{Rp} 79.200 .000$,- dengan rata-rata per responden $\mathrm{Rp}$ 3.960.000/ha.

\section{Mulsa}

Mulsa digunakan sebagai sarana dalam menanam tomat, sehingga memerlukan banyak mulsa baik plastik dan polybag plastik. Mulsa plastik yang digunakan 20 responden adalah 469 rol, dengan rata-rata setiap responden menggunakan 23 rol. Harga 
mulsa plastik Rp. 700.000,-/rol jadi jumlah biaya untuk mulsa plastik adalah Rp. 328.440.000,- dan rata-rata responden mengeluarkan biaya Rp. 16.422.000,-.

Polibag plastik yang digunakan untuk 20 responden sejumlah 1.017 bungkus, dengan rata-rata setiap responden menggunakan 51 bungkus. Harga polibag plastik ratarata Rp. 17.000,-/bks jadi jumlah biaya untuk 20 responden adalah Rp. 17.282.200,- dan untuk masing-masing responden rata-rata Rp. 864.110,-.

Jadi total biaya yang dikeluarkan untuk mulsa oleh 20 responden adalah $\mathrm{Rp}$. 345.722.200,- dan rata-rata responden mengeluarkan biaya Rp.17.286.110,-.

\section{Pupuk}

Pupuk yang digunakan petani tomat adalah Pupuk kandang, Ponska, TSP/SP36, NPK hitam, KNO3, Atonik dan Metalik. Dalam penelitian ini, tidak semua jenis pupuk digunakan oleh petani responden dalam kegiatan usaha taninya.

Jumlah Pupuk kandang yang digunakan oleh 20 responden adalah $117.300 \mathrm{~kg}$ dengan rata-rata per responden $5.865 \mathrm{~kg}$ responden dengan harga rata-rata $\mathrm{Rp} 170 / \mathrm{kg}$ dan jumlah biaya pupuk kandang adalah Rp 19.941.000,- dengan rata-rata per responden Rp 997.050,-.

Jumlah Pupuk Ponska yang digunakan oleh 20 reponden adalah $8.602 \mathrm{~kg}$ dengan rata-rata per responden $430 \mathrm{~kg}$ dengan harga rata-rata $\mathrm{Rp} .8 .000 / \mathrm{kg}$ dan jumlah biaya pupuk Ponska adalah $\mathrm{Rp} 68.816 .000$,- dengan rata-rata per responden $\mathrm{Rp}$ 3.440.800,--

Jumlah Pupuk TSP yang digunakan oleh 20 reponden adalah $1.369 \mathrm{~kg}$ dengan rata-rata per responden $68 \mathrm{~kg}$ dengan harga rata-rata $\mathrm{Rp} 2.500 \mathrm{~kg}$ dan jumlah biaya pupuk TSP adalah Rp 3.421.250,- dengan rata-rata per responden Rp 171.063,--

Jumlah pupuk NPK yang digunakan oleh 20 responden adalah $3.128 \mathrm{~kg}$ dengan rata-rata per responden $156 \mathrm{~kg}$ dengan harga rata-rata $\mathrm{Rp} 9.000 / \mathrm{kg}$ dan jumlah biaya pupuk NPK adalah Rp 28.152.000,- dengan rata-rata per responden Rp 1.407.600,-.

Jumlah Pupuk KNO3 yang digunakan oleh 20 responden adalah $1.642 \mathrm{~kg}$

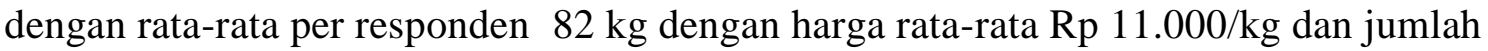
biaya pupuk mutiara adalah $\mathrm{Rp} 18.064 .200$,- dengan rata-rata per responden $\mathrm{Rp}$ 903.210,-.

Jumlah Pupuk Atonik yang digunakan oleh 20 responden adalah $15.640 \mathrm{ml}$ dengan rata-rata per responden 782 dengan harga rata-rata $\mathrm{Rp} 50,-/ \mathrm{ml}$ dan jumlah biaya pupuk Atonik adalah Rp.782.000,- dengan rata-rata per responden Rp 39.100,-.

Jumlah Pupuk Metalik yang digunakan oleh 20 responden adalah $7.820 \mathrm{ml}$ dengan rata-rata per responden $391 \mathrm{ml}$ dengan harga rata-rata $\mathrm{Rp} 125,-/ \mathrm{ml}$ dan jumlah biaya pupuk Metalik adalah Rp.977.500,- dengan rata-rata per responden Rp 48.875,-

Jadi total biaya pupuk adalah Rp 140.153.950,- dengan rata-rata per responden adalah Rp 7.007.698,-- 


\section{Pestisida}

Pestisida yang digunakan petani tomat adalah Curacron, Dithane, Roundup dan Pelekat (APSA). Dalam penelitian ini, tidak semua jenis pestisida digunakan oleh petani responden dalam kegiatan usahataninya.

Jumlah Curacron yang digunakan oleh 20 responden adalah 156 liter dengan rata-rata per responden 8 liter dengan harga rata-rata Rp.43.000/lt dan jumlah biaya pestisida Curacron adalah Rp 6.725.200,- dengan rata-rata per responden Rp 336.260,-

Jumlah Dithane yang digunakan oleh 20 responden adalah $156 \mathrm{~kg}$ dengan ratarata per responden $8 \mathrm{~kg}$ dengan harga rata-rata $\mathrm{Rp} .60 .000 \mathrm{~kg}$ dan jumlah biaya pestisida Gramoxon adalah $\mathrm{Rp}$ 9.384.000,- dengan rata-rata per responden $\mathrm{Rp}$ 469.200,-.

Jumlah Roundup yang digunakan oleh 20 responden adalah $31.280 \mathrm{ml}$ dengan rata-rata per responden $1.564 \mathrm{ml}$ dengan harga rata-rata $\mathrm{Rp} .100 / \mathrm{ml}$ dan jumlah biaya pestisida Roundup adalah Rp 3.128.000,- dengan rata-rata per responden Rp 156.400,-

Jumlah Pelekat (APSA) yang digunakan oleh 20 responden adalah $78.200 \mathrm{ml}$ dengan rata-rata per responden $3.910 \mathrm{ml}$ dengan harga rata-rata $\mathrm{Rp} .20 / \mathrm{ml}$ dan jumlah biaya pestisida Pelekas (APSA) adalah Rp 1.564.000,- dengan rata-rata per responden Rp 78.200,-.

Total biaya pestisida adalah Rp 20.801.200 dengan rata-rata per responden adalah Rp 1.040.060,-.

\section{Tenaga Kerja}

Tenaga Kerja yang digunakan petani tomat adalah untuk pengolahan lahan, persemaian, penanaman, pemupukan, penyiangan, pengendalian HPT dan panen. Tenaga kerja yang digunakan adalah tenaga kerja pria dan wanita dalam usia produktif (15 - 64 tahun).

Jumlah tenaga kerja pada proses pengolahan lahan yang digunakan oleh 20 reponden adalah 391 orang dengan rata-rata per responden 20 orang dengan upah ratarata $\mathrm{Rp} 45.000 / \mathrm{HOK}$.

Jumlah tenaga kerja pada proses persemaian yang digunakan oleh 20 reponden adalah 391 orang dengan rata-rata per responden 20 orang dengan upah rata-rata $\mathrm{Rp}$ 35.000/HOK.

Jumlah tenaga kerja pada proses penanaman yang digunakan oleh 20 reponden adalah 391 orang dengan rata-rata per responden 20 orang dengan upah rata-rata $\mathrm{Rp}$ 35.000/HOK.

Jumlah tenaga kerja pada proses pemupukan yang digunakan oleh 20 reponden adalah 235 orang dengan rata-rata per responden 12 orang dengan upah rata-rata $\mathrm{Rp}$ $35.000,-/ \mathrm{HOK}$

Jumlah tenaga kerja pada proses penyiangan yang digunakan oleh 20 reponden adalah 78 HOK dengan rata-rata per responden 4 HOK dengan upah rata-rata Rp $45.000,-/ \mathrm{HOK}$ 
Jumlah tenaga kerja.pada proses pengendalian HPT yang digunakan oleh 20 reponden adalah $78 \mathrm{HOK}$ dengan rata-rata per responden 4 HOK dengan upah ratarata $\mathrm{Rp} 45.000 / \mathrm{HOK}$.

Jumlah tenaga kerja pada proses panen yang digunakan oleh 20 reponden adalah 391 HOK dengan rata-rata per responden 20 HOK dengan upah rata-rata Rp 45.000/HOK.

Total biaya tenaga kerja adalah Rp 186.898.000 dengan rata-rata per responden adalah $\mathrm{Rp}$ 9.344.900.

Jadi total biaya variabel dari Kelompok Tani Karya Maju adalah Rp. 36.227.128,-/musim dan terangkum dalam tabel di bawah ini :

\section{Total Biaya}

Total biaya adalah biaya yang dikeluarga oleh Kelompok Tani Karya Maju yang meliputi biaya tetap dan biaya variabel. Adapun biaya yang dikeluarkan tercantum dalam tabel di bawah ini.

Tabel 4.5 Analisis Usaha Tani Tanaman Tomat (Solanum lycopersicum L.) Di Kelompok Tani Karya Maju skala per hektar (ha).

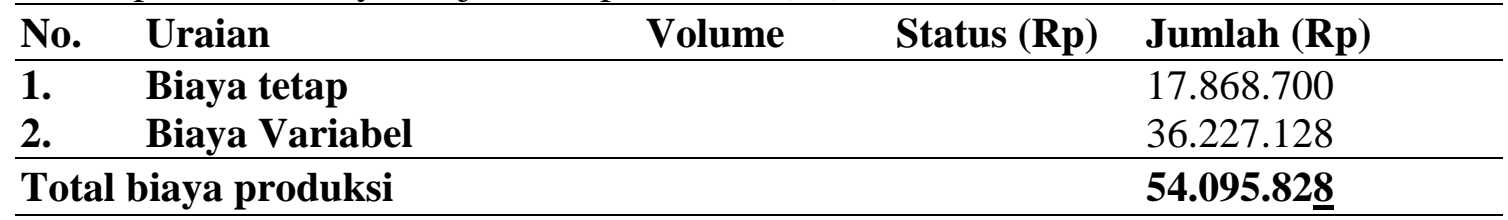

Sumber : Diolah dari hasil wawancara penelitian, 2015

\section{Penerimaan Usaha Tani Tomat}

Rata-rata pemasukan yang diterima Kelompok Tani Karya Maju sebesar Rp. 98.900.000,- dalam satu musim panen dari kegiatan ekonomi yang menghasilkan uang tanpa dikurangi dengan total biaya produksi yang dikeluarkan. Penerimaan itu didapat dari jumlah hasil panen tomat sejumlah $19.780 \mathrm{~kg}$ dikalikan dengan harga pasaran.

\section{Pendapatan}

Penerimaan $=19.780 \mathrm{~kg} \times$ Rp.5.000 = Rp. 98.900.000,-/musim.

Dari analisa usaha tani tomat pendapatan yang di dapat Kelompok Tani Karya Maju sebesar Rp. 44.804.822,-/musim, pendapatan total penerimaan setelah dikurangi dengan biaya produksi, kalau pendapatan itu positif maka akan di sebut keuntungan atau (laba) sedangkan pendapatan negatif di sebut dengan (rugi). Dengan perhitungan sebagai berikut :
a. Peneriman usaha tani
Rp $5.000 \times 19.780 \mathrm{~kg} \quad$ : $\quad$ Rp 98.900.00,-
b. Biaya usaha tani
: $\quad \operatorname{Rp}_{2}, \mathbf{5 4 . 0 9 5 . 8 2 8}$
Pendapatan usaha tani
Rp 44.804.822,-

Jadi dari hasil pendapatan Rp. 44.804.822,-/musim yang mana pendapatan ini bernilai positif, sehingga bisa dikatakan kelompok Tani Karya Maju mengalami keuntungan. 


\section{Analisis Kelayakan Usaha Tani (R/C Ratio)}

( $\mathrm{R} / \mathrm{C}$ ratio) biasa digunakan dalam analisis kelayakan usaha tani, yaitu perbandingan antara total peneriman dan total biaya yang dikeluarkan.

$\begin{aligned} \mathrm{R} / \mathrm{C} \text { Ratio } & =\frac{\text { Peneriman usaha tani }}{\text { Biaya usaha tani }} \\ & =\frac{\operatorname{Rp} 98.900 .000,-}{\operatorname{Rp~54.095.828}} \\ & =1.8\end{aligned}$

Nilai R/C Ratio sebesar 1,8 menunjukan bahwa dari biaya yang dikeluarkan sebesar Rp. 54.095.828,-/musim akan diperoleh penerimaan sebesar 1,8 kali lipatnya. Dengan kata lain, hasil penjualan tomat ini mencapai $1,8 \%$ dari modal yang dikeluarkan. Nilai R/C Ratio lebih besar dari 1, menunjukkan bahwa usaha tani tomat tersebut layak dikembangkan.

\section{Analisis Titik Impas Pulang Modal (BEP)}

Analisis titik impas pulang modal atau Break Event Point (BEP) adalah suatu kondisi yang menggambarkan hasil usaha tani yang diperoleh sama dengan modal yang dikeluarkan. Dalam kondisi ini, usaha tani yang dilakukan jika dilihat dari pendapatan tidak menghasilkan keuntungan tetapi juga tidak mengalami kerugian.
a. $\mathrm{BEP}$ volume produksi $=\underline{\text { Total biaya usaha tani }}$
Harga Penjualan
$=\quad \underline{\operatorname{Rp} 54.095 .828}$
$\operatorname{Rp} 5.000,-$
$=\quad 10.819$

Hasil ini menunjukkan bahwa pada saat diperoleh produksi sebesar $10.819 \mathrm{~kg}$, maka pendapatan petani tidak akan diperoleh keuntungan maupun kerugian.
b. BEP harga produksi = $\quad$ Total biaya usaha tani
Total produksi
$=\quad \underline{R p ~ 54.095 .828,-}$
$19.780 \mathrm{~kg}$
$=\quad 2.734,-$

Hasil ini menunjukkan bahwa saat harga tomat di tingkat petani sebesar Rp 2.734 maka pendapatan usaha tomat tersebut tidak memberikan keuntungan maupun kerugian.

\section{KESIMPULAN}

Dari hasil penelitian maka dapat disimpulkan yaitu Analisis usahatani tomat di Kelompok Tani Karya Maju mengalokasikan sumber daya yang ada secara efektif dan efesien untuk pendapatan memperoleh keuntungan pada waktu tertentu sebesar Rp. 44.804.822/musim. Serta analisis finansial usahatani tomat di Kelompok Tani Karya Maju untuk mengetahui apakah usaha tani yang dilakukan layak dan menguntungkan untuk dikembangkan atau dikatakan masih dalam tingkat efensiensi. Nilai R/C Ratio sebesar 1,8 menunjukan bahwa dari biaya yang dikeluarkan sebesar Rp. 98.900.000,- 
/musim akan diperoleh penerimaan sebesar 1,8 kali lipatnya. Dengan kata lain, hasil penjualan tomat ini mencapai $1,8 \%$ dari modal yang dikeluarkan. Nilai R/C Ratio lebih besar dari 1, menunjukkan bahwa usaha tani tomat tersebut layak dikembangkan.

\section{SARAN}

Hasil penelitian menunjukkan bahwa usahatani tomat di Kelompok Tani Karya Maju Desa Mandesan Kecamatan Selopuro Kabupaten Blitar layak untuk diusahakan, maka itu disarankan agar petani dapat meminimalkan pengeluaran biaya pengelolaan usahataninya agar pendapatannya lebih meningkat seterusnya. Dalam penanaman tanaman tomat baik menggunakan mulsa plastik hitam perak

\section{DAFTAR PUSTAKA}

Aditya, B, 2009. Budidaya Tanaman Tomat. http://www.budidaya. Diakses pada tanggal. 28. maret.2013.

Anonim, A, 2009. Teknologi Budi Daya Tanaman Pangan.

Anonymouse. 1996. Usaha Mikro, Kecil dan Menengah. Rajawali. Jakarta.

Boediono. 1993. Manajemen Usaha Mikro. Aneka Pustaka. Jakarta

Cahyono, B. 1998. Tomat Budidaya dan Analisis Usaha Tani. Kanisius, Yogyakarta.

Cahyono,B. 1998.Tomat Budidaya. Kanisius. Yogyakarta.

Dyckman. 2002. Manajemen usahatani. Kanisius. Yogyakarta

Kadariah. 1983. Teori Ekonomi Mikro. Fakultas Ekonomi, UI.

Mubiarto,Pengantar Ekonomi Pertanian,LP3ES.Jakarta.

Mulyadi. 2005. Pengantar Ekonomi Pertanian. Edisi 3. LP3ES, Jakarta.

Pracaya, 2000. Tomat-Tomatan. Penebar swadaya. Jakarta.

Rahardi, F. Y. H. Indriani dan Haryono. 1997. Agribisnis Tanam Buah. Penebar Swadaya, Jakarta.

Rahim, M dan Hastuti, 2008. Manajemen Agribisnis dan Faktor-faktor Agribisnis. Rajawali. Jakarta

Rianto. 1997. Manajemen Ekonomi. Rajawali. Jakarta

Rikar, 2008.Perbedaaan antara Pendapatan dan Peneriman http://www. peneriman. Diakses pada tanggal.31.Agustus.2015.

Rukmana, R. 1994. Budidaya Tanaman Tomat-Tomatan. Kanisius, Yogyakarta.

Rukmana, R. 1994. Tomat dan Cherry. Kanisius, Jakarta.

Samuelson, P. A dan W. D Nordhaus. 2003. Ekonomi Mikro. Edisi 14. Erlangga, Jakarta.

Soedarsono. 1992. Pengantar Ekonomi Mikro. Edisi Perisi. LP3ES, Jakarta.

Sogeng, 2013. Budidaya Tomat. http://www.teknologi_pangan. iptek.net.id/ind/phd? id. Diakses. tanggal 28. maret.2015.

Soeharjo, a. dan D. patang. 1994. Sendi-sendi Pokok Ilmu Usaha Tani. Faperta Unhas, Ujung Pandang.

Soekantawi. 1988. Prinsip Dasar Manajemen Hasil-Hasil Pertanian. Rajawali, Jakarta.

Soekartawi,1995.Ilmu Usaha Tani.Universitas Indonesia UI Press.Jakarta

Soekartawi. 1994. Membangun Pertanian. Kaya Grafindo Persada, Jakarta. 
Soekirno, S. 2002. Pengantar Ekonomi Mikro. Edisi 3 Cetakan 17. Raja Grafindo Persada, Jakarta.

Sugeng,1981.Bercocok tanam sayuran. Aneka ilmu Semarang.

Sunarjono. 2000. Pengembangan Usaha Tani dan Faktor-faktornya. Pustaka Ilmu. Jakarta

Suratiyah, 2009.Pedoman Bertanam Sayuran Dataran Rendah. Universitas Gajah Mada Press. Yogyakarta.

Suteja, M. 2002.Pupuk dan cara pemupukan. PT. Rineka cipta. Jakarta.

Tjahjadi, Nur. 1996.Hama dan penyakit tanaman. Kanisius. Yogyakarta.

Winardi. 1998. Aspek-Aspek Bauran. Pemasaran (Marketing Mix). Mandar Maju, Bandung. 